\title{
Présentation de Rainer Warning
}

\section{Wolfram Nitsch}

\section{OpenEdition}

\section{Journals}

Édition électronique

URL : https://journals.openedition.org/ccs/452

DOI : $10.4000 /$ ccs 452

ISSN : 2558-782X

\section{Éditeur :}

Presses universitaires de Rennes, Association des lecteurs de Claude Simon

\section{Édition imprimée}

Date de publication : 30 juin 2005

Pagination : 99-101

ISBN : 2914518676

ISSN : 1774-9425

Référence électronique

Wolfram Nitsch, "Présentation de Rainer Warning », Cahiers Claude Simon [En ligne], 1 | 2005, mis en ligne le 20 septembre 2017, consulté le 01 mars 2022. URL : http://journals.openedition.org/ccs/452 ; DOI : https://doi.org/10.4000/ccs.452 


\section{Lectures étrangères}



Parmi les romanistes allemands des dernières décades, Rainer Warning est sans doute l'un des plus importants. Né en 1936 et formé par l'"École de Constance ", notamment par Hans Robert Jauss, il a été professeur de littérature française et comparée à l'Université de Munich de 1972 à 2002. En tant que membre du prestigieux groupe de recherche "Poetik und Hermeneutik », il était parmi les premiers à introduire dans les débats allemands la critique structuraliste et sémiologique, l'archéologie du discours et la théorie de la déconstruction, non sans élaborer tous ces paradigmes à partir d'une tradition d'anthropologie philosophique peu présente dans les débats français. Mais loin d'étudier la théorie littéraire pour ellemême, il l'a toujours mise au service de la lecture des textes. Ceci se voit en particulier dans ses études sur la comédie, sur le jeu liturgique (Funktion und Struktur, 1974) ou sur la poésie française et italienne (Lektüren romanischer Lyrik, 1997), mais également dans ses travaux sur le roman de Diderot (Illusion und Wirklichkeit, 1965), des réalistes (Die Phantasie der Realisten, 1999) et de Proust (ProustStudien, 2000). Parmi les successeurs contemporains de Proust, c'est surtout Claude Simon qui a suscité son intérêt critique. L'article suivant, dont la version originale a paru en 1991, a fait époque dans les recherches simoniennes d'outre-Rhin. 